\title{
Poesía
}





\section{Diego Otero}

\section{Memorandum of Birds}

\section{Autorretrato}

Tú eras de la raza aquella que se atora de luces

$$
\text { y calla }
$$

torpemente,

y convoca los dones de las más pequeñas

cosas

que se asombran:

un acorde

una ventana muerta

una pluma

que viaja sola en

la neblina. 
2. Escribiremos un buen poema

cuando empeñemos la llave

de la Casa de la Risa y

nos riamos,

cuando el mudo corazón de un pájaro

sea más pesado

que los hilos de viento que lo elevan,

cuando llueva-

cuando sea lluvia un nombre propio.

3. Hasta el final

te seguiré queriendo

con delicadeza,

como quien prepara la tumba de los pájaros. 


\section{BREVE ESTUDIO DE LA INDIFERENCIA}

He visto morir a un hombre viejo

con una violeta inexplicable entre

las manos.

Hay algo vertebrado

en las luces que lo envuelven

y ajeno

(La radio sintonizada en el vacío / una violeta inexplicable).

\section{Pero caen mis ojos}

de papel y

ruedan

hasta los delicados pies de Nadie.

Y un gato absurdo

y amarillo

es quien contempla de lejos el silencio-

y es el corazón mismo del acero,

la indiferencia.

La sucia

lealtad de las violetas. 


\title{
Homenaje a un Reloj SIN MANECillas
}

\author{
Y se nos cuarteará la voz
}

como la espina de los peces fulminados

por la luna

porque un día fuimos

divinamente frágiles

y necios

y jamás

supimos recibir

el extraño don de las paredes.

Tú me entiendes-

las paredes.

-Mira:

en mis ojos no existe nada

sino una bola de mariposas

muertas.

(Señoras y señores, temo informarles

que a veces un remordimiento es una lluviaun caballo de agua que inunda nuestra casa

y brota de los techos,

los cajones,

y nos persigue

mordido de sombra

en los pasillos,

$$
\begin{aligned}
& \text { el retrete, } \\
& \text { el desfigurado rostro }
\end{aligned}
$$

del tipo que lee las noticias). 
¿Sabías que en el cielo

hay un piano

que guarda el esqueleto de Chopin?

¿lo sabías?

¿Sabías que un perro cegado de

pétalos

lo conduce

como a una carroza entre las nubes

y lo ayuda a reír

$$
\text { y a defecar? }
$$

¿Sabías que somos niños

persiguiendo luciérnagas

migajas de luz

en las habitaciones

más opacas

del Palacio de las Sombras?

¿Sabías que todos los cuerpos

son juguetes cansados y torcidos,

y que sus tristes labios

son de nadie

y para nadie?

Anoche tuve náuseas,

y dejé en la sala un plato

con un poco de carne,

cebollas

y arroz mal preparado. 


\section{Cenarán los pájaros}

la inmundicia

$$
\begin{gathered}
\text { el encantado esqueleto } \\
\text { de Chopin. }
\end{gathered}
$$

Only emotion remains

in our glass of blood.

Sólo la emoción.

Pero somos niños

y somos crueles

y hemos arrojado piedras y latas

hasta matar

al viejo mago

que perdió el empleo.

Ya nadie nos hará soñar.

Si hay una palabra que agoniza

es la palabra asombro

-llamen a un médico.

Yo solía vivir

como un

niño amotinado de fulgores.

Yo solía vivir.

El esqueleto encantado

de Chopin

el Sol

la inmundicia

Pianíssimo

Pianíssimo. 


\section{EN EL MEJOR DE LOS SILENCIOS (BOCETO PARA UNA PERFORMANCE)}

Un hombre sube lentamente a un escenario. No es un torero desahuciado pero lleva un traje de sombras / y el equivocado corazón de un pájaro que calla y huele a mar. Mira al suelo unos segundos y pasa saliva, como quien se traga la inocultable mueca de la desprotección y, luego, minuciosamente, repasa con los ojos el marchito color de las butacas. Todo su público es un cuervo, una luciérnaga despiadada y una niña. Para qué más, acaso piensa el hombre, mientras coloca el corazón sobre una pequeña mesa en la que hay una larguísima botella y un caracol hecho de luz. Al fondo, una mujer desnuda cruza el escenario y arrastra, con una enorme cadena, una nube como un fantasma mutilado. Algo no está funcionando bien aquí, dice repentinamente el hombre, abriendo los ojos con violencia, como dos platos donde hubieran comido con las manos la envidia y el pavor. Yo debería tener un par de alas, una bicicleta blanca, y un corazón dorado que palpite como el capullo de un temblor. Pero ya ven, me obligaron a subir a un escenario, solo, con estos trapos robados al peor apóstol de la lluvia. Sí, es verdad. Yo debería tener un corazón y no este hueco en el que alguien arrojó un espejo, una gota de sangre y un reloj histérico. El hombre se da media vuelta. Queda el eco brevemente y sus palabras caen sobre la madera astillada, y se quiebran como copas de vidrio, como burbujas que son bellas porque vuelan y transparentan y son nada. Luego, en el mejor de los silencios. 


\section{UN VIEJO FOTOGRAMA}

Digamos que es un patio. Uno sin nombre

y que se ha puesto tímido de pájaros

y brilla

cubierto de cera

como el corazón de

las personas que están solas

y llevan una flor de huracán

en los bolsillos,

en las carteras.

En el filo de la

noche,

el bailarín que ha viajado hasta tu voz

transforma la música

en ventanas,

la luz ha huido de las habitaciones

$y$ es un brazo enorme

de jade desplomándose,

liquidando al bailarín

liquidando al bailarín

liquidando al bailarín

como un viejo fotograma

repetido al infinito.

(El proyeccionista se ha quedado dormido. El café está medicamente muerto y lo vela con esmero la sombra de una mariposa -una sombra como un tatuaje vivo-. Las máquinas escupen ruidos secos. Y abajo, en las butacas, la gente silba y se endurece, porque siempre será un pecado detener el tiempo). 
Digamos que es un patio. Uno sin nombre y se ha vuelto tímido

de pájaros

y es nuestro

como es nuestra la ansiedad o la certeza de la risa.

\section{Y así giramos}

niños,

$$
\text { y giramos }
$$

y es muy simple:

aprendemos a imantar el desconcierto 
